\title{
Subtitling as a Teaching Tool for English for Specific Purposes' Students
}

\section{Buil-Beltrán, Paula}

Department of English and German Philology, University of Zaragoza, Spain.

\begin{abstract}
New technologies have invaded our daily lives, and as a consequence the use of computers and internet inside the classroom is progressively more frequent. At the same time, subtitling as a teaching/learning tool has become more popular. For that purpose, scholars such as Delabastita (1989), Sokoli (2006) or Talaván (2013) have been researching how the adaptation of these subtitling methods will have some influence in the learning/teaching process. Thus, the aim of this paper is to present an interlingual subtitling task in a class for English for Specific Purposes students (from a university degree of architecture), in order to improve their receptive skills (commonly known as listening and reading). Along these lines, this paper will explore the use of Task Based Learning in ESP classes and it will propose a teaching unit for further implementation in a university class of English for the degree of architecture, discussing the advantages and repercussions it may have for the acquisition and improvement of the aforementioned passive skills.
\end{abstract}

Keywords: Subtitling; English for Specific Purposes; Task Based Learning; Passive Skills; Architecture. 


\section{Introduction}

The study of language teaching is something as old as time. There are theories that go back to the $16^{\text {th }}$ Century. These theories prioritized grammar for the acquisition of a new language, however, a great amount of communication teaching can be also found, namely Brumfit \& Johnson, 1979, Krashen \& Terrell, 1983, Prabhu, 1987, Nunan, 1989. Since the implementation and development of technology, the focus of language research has changed, in order to adapt the studies to new improvements, combining technology with communication language teaching theories. For instance, recent studies have found that the use of video and subtitles, not only as a passive but also as an active tool, may help L2 students to develop better communication skills.

Along these lines, this paper will try to give a new overlook in this latest theory. It will combine a well-known teaching theory, Task Based Learning (TBL) with the introduction of a subtitling task in an English for Specific Purposes (ESP) class. The target students will be university students of the degree of architecture who attend an elective class of ESP with a B1/B2 level according to the Common European Framework of Reference for Languages (Council of Europe, 2001).

Thus, this preliminary study will be divided in three different parts. The first part will deal with TBL approach. The second part will introduce ESP and its main features to understand the needs of the students to which the project will be applied for. Finally, the third section will give a lesson example using subtitling as the main teaching tool and with the aim of further implementation in a real university class. During this last section, the use of subtitling videos inside the classroom will be explored including the justification of the selected corpus and a final part with the activity per se.

\section{Task Based Learning Theory}

Communicative Language Teaching theory (CLT) can be said to be born during the $80 \mathrm{~s}$ through the researches made by Littlewood (1981) and Brumfit (1984). It tried to break with the established teaching methods, mainly based on the grammar teaching/learning. It is an open approach, which may be something positive as it has different motivations for language learning, and different kinds of teachers and individual students' needs. Moreover, as it is such an open approach that includes different interpretations which lead, at the same time, to other theories as the one that concerns this paper, TBL.

TBL theory has its origins on Prabhu (1987) studies, where he described second language acquisition methods giving an introduction to this new theory. It was followed by Nunan (1989) and Willis (1996), who took a deeper look in this new methodology. The main goal 
of TBL is to present common situations to the students through the use of different tasks (Talaván, 2013).

One of the most important aspects of this theory is the so called learning by doing, which means that students learn through interactive tasks instead of using the traditional methods of presentation and practical repetition of linguistic elements. Nowadays, one of the most practical ways of achieving this is through the use of audiovisual media, and it is at this point where the use of new technologies (TIC) plays an important role.

This theory may have a great impact on ESP students, whose main goal is to acquire a reading knowledge that helps them in their future professional careers. This is the reason why, according to Willis (2016:7), the tasks may be based on a text presented in the L2 and the activities performed could be done on the students' mother tongue. It is at this point where a subtitling active task, as the one that will be presented in section 4, may be useful for the students, as its aim will be to work with a text in a foreign language and provide its translation into the student's mother tongue.

\section{English for Specific Purposes}

Over the last few decades, English has become the language employed in different specialized working areas. This is the reason why, the study of the distinctive features of English has become one of the most successful research fields (Fuertes Olivera \& Samaniego Fernández, 2005). Moreover, this has also modified the students profile and their necessities, due to the fact that people in general have more opportunities to travel, either for working or tourism.

In this line, scholars like Català-Hall (2013:1) defined ESP as specific courses designed in order to answer the immediate necessities of the students that need practicing English in specific professional areas. According to Fuertes Olivera \& Samaniego Fernández (2005), the term ESP has two different connotations, one for the pedagogical area that is, teaching English in different specialist areas such as economics or architecture, and another one in a more general area, using English in highlighted communicative situations. Both connotations are important in this study, as the main goal of the students will be to improve their English for their future careers.

Dudley-Evans \& St. Johns (1998) agreed on a series of aspects that ESP may have, dividing them in absolute and variable characteristics. Some of the ones that concern this study are: 1) ESP is designed to meet specific needs of the learners, 2) ESP is centered on the language appropriate to these activities in terms of grammar, lexis, register, study skills, discourse and genre, 3) ESP may be related to or designed for specific disciplines, and ESP 
may use, in specific teaching situations, a different methodology from that of General English (Dudley-Evans \& St. Johns, 1998: 4-5).

Finally, it is worth mentioning that there are several types of ESP teaching, such as English for Academic Purposes (EAP) or English for Occupational Purposes (EOP). However, at the present, the most important one is the described above and English for Specific Academic Purposes (ESAP), which can be described as the English employed by university students during their academic researches and the publications that gather their findings (Jordan, 1997). Even so, this study has its main goal in ESP, as the students tested during the research are university students under a degree in architecture.

\section{Subtitling as a learning/teaching tool}

Nowadays, younger generations, are more used to learn through the use of TICs than through books, Caimi (2003). This is one of the reasons why the use of subtitles, which are defined by Diaz Cintas (2003: 195) as "written text [...] giving an account of the actors' dialogue and other linguistic information which form part of the visual image (letters, graffiti, and captions) or of the soundtrack", is a regular tool in the classrooms. Numerous are the researches in the field of the passive use of subtitles inside the classroom since their use seems to have a considerable pedagogical potential.

The use of subtitles in a passive and in an active way, where students have to create their own subtitles, is not really spread yet, as Letorla points out (2012). However, there are successful projects that prove its effectiveness. An example of this is LeViS (Socrates) funded by the European Commission Lifelong Learning Programme (Letorla, 2012). The study presented in this paper is going to propose a teaching unit whose main focus will be the creation of interlingual subtitles, taking into consideration Letorla's (2012:63) assumptions that "it has been suggested that human beings are able to remember $10 \%$ of what they heard, $20 \%$ of what they visually perceive, and $80 \%$ of what they visually perceive and interact with".

Finally, it is also important to highlight some of the advantages that Sokoli (2006) proposed for the use of subtitled audiovisual material in class. According to her, this material provides the student with three different learning methods (spoken language, printed text and visual information). It also helps both beginners and experienced learners to acquire general contents and vocabulary, and it could tear down the existing barrier between passive skills. 


\subsection{A Teaching Unit for further implementation}

As has been previously mentioned, this paper is going to provide a teaching unit based on TBL for further implementation on a university class of ESP. In order to do so, a clip has been chosen to achieve the goal of improving the passive skills of the target students. Thus, a justification of its selection is going to be provided and then there will be a brief description of some activities that will be introduced during the class, dividing them in previewing activities, viewing activities and post-viewing activities.

The selected class will be, as it is previously mentioned, a group of ESP students in the University of Zaragoza. Thus, the experimental group during this study will attend a class called "Inglés Específico I". This is an elective course offered at the degrees of engineering and architecture in order to improve the students' English skills. This course is divided in several modules, has one-year duration, and is rewarded with 4 ECTS credits. In order to course this subject, the students are required to have a B1 level, in accordance to the Common European Framework of Reference for Languages (Council of Europe, 2001), and the aim is to end up the course with a B2 level. This course has a professional and academic focus on the study and practice of the English language, aimed at the technical field. It is also important to highlight, that having a good level of common English might be useful, but the importance of the course deals with the domain of English as a technical language.

Hence, the corpus selection has been made according to some factors, although the conclusive one has been the students for which the activities will be created for. The clip is called "Don't build your home, grow it" (Joachim, 2010). As the teaching unit is oriented to architecture students, the clip presents an architectural proposal that can be of interest for the selected students. At the same time, it is a short clip, with a length of 2 minutes and 50 seconds, which does not need to be cut for its use in class and may be suitable for a class with a maximum capacity of 30 students. Besides, the website that the video has been taken from (TED talks) offers the possibility of viewing its clips with or without subtitles, and it also gives the opportunity of downloading not only the clip but also the original script. Another important factor has been that it is an authentic video, which means that the speaker uses real language with hesitations and typical spoken language characteristics. Finally, it is also important to mention some of the linguistic characteristics that the video has. The speaker uses different grammatical structures, from present simple or progressive to past forms or conditionals, which makes the dialogue rich and suitable for the selected level (B1/B2). It also has a copious and very specific vocabulary, which may arouse the interest of a student who attends an ESP class.

The teaching unit will be divided in three different parts: pre-viewing, viewing and postviewing. As Caimi (2013) points out, this type of activities are good in teaching contexts that made used of subtitling tasks, as it helps students to watch and work with the selected 
video being aware of the tasks. Thus, during the pre-viewing activities the students will become aware of the video they are going to visualize; during the viewing activities they will have a chance of comprehending the video, reading the script and doing the main task; and finally, during the post-viewing activities, they will be able to show what they have learnt and express themselves with a short activity that may help them to develop the active skill of writing.

Hence, at the beginning of the class, the teacher will give the students just the title of the video they are going to watch, and s/he will encourage them to do a brainstorming to activate their previous English knowledge and discuss what the video may be about. After the brainstorming, the teacher will give them a short question/answer test about what they think the video could be about, helping them to have a better idea of what they are going to watch and activating their comprehension skills.

The second part of the class, or the viewing part, will start after the test. First, the teacher will play the video with audio but without image. During this process, the students will have the original script, with blank spaces to fill out while listening to the audio. During this part, the listening comprehension skill will be activated. Finally, the main task will be introduced. Now that the students have their original script complete, the teacher will play the video a second time; however, this time will be with both, audio and image on. In this part of the class, they will have to translate the video to their mother tongue, working with listening and reading skills.

The post-viewing part will consist of the final subtitling of the video, with their transcript the students will have to adjust the dialogues to the screen using the program Aegisub and taking care of the formal aspects of subtitling. To finish, the teacher will give them a question that they will have to answer according to their opinions: Do you think that the introduction of new materials in architecture will benefit architecture progress? Justify your answer.

These activities may help them to develop the four different commonly known skills, starting by a brief speaking debate while doing the brainstorming and ending up with a short composition of what they have learnt. However, the two most important aspects that the students will work with will be listening, as they have to complete the script by themselves, trying to understand every gist of the video, and reading, as they will have to read carefully and understand the text if they want to do a good translation.

\section{Conclusion}

The aim of this paper was to take a deeper look on TBL theory, in order to apply them to a further study on the use of subtitles as an active tool in a classroom of ESP. This paper 
forms part of a wider study on the improvement of passive skills, listening and reading, in a class of ESP, which will be applied next year at the University of Zaragoza. One of the aims of this paper was to prove how previous theories can be adjusted and adapted to the new improvement in technology that has been made in the past few years. I firmly believe that the use of new tools inside the classroom can foster students learning and interest for English language.

Hereof, this paper has given a brief summary of the former theory, trying to apply it to the students that the study will be oriented to. It has shown that it may be useful for further researches on the field of the use of video and subtitles inside the classroom. It has also taken a look on the definition and main characteristics of ESP students, presenting a homogeneous group that will be used in order to prove the main theory of this study. Finally, it has introduced a teaching unit that will function as a guide for further study and implementation.

In the future, the perspectives are good. Every year more researchers are investigating on the use of subtitles inside the class. At this respect, this paper's aim is to be implemented, together with some other teaching units, in a class of ESP students in the University of Zaragoza. Once the study has been applied, conclusions can be draft on how effective this new methodology could be in order to improve, primarily, the students' passive skills. This will help ESP students to develop a better comprehension of documents and oral English, which may help them to develop their future careers.

\section{References}

Brumfit, C. (1984). Communicative Methodology in Language Teaching: The Roles of Fluency and Accuracy. Cambridge: Cambridge University Press.

Brumfit, C., \& Johnson, K. (1979). The Communicative Approach to Language TEaching. Oxford: Oxford University Press.

Caimi, A. (2013). Subtitles and language learning. In Y. Gambier, \& L. Doorslaer, Handbook of Translation Studies (pp. 167-173). Amsterdam: John Benjamins Publishing Company.

Catalá-Hall, A. (2013, April 16). Inglés con fines específicos. Retrieved from Diccionari de lingüistica on line: http://www.ub.edu/diccionarilinguistica

Council of Europe. (2001). Common European Framework of Reference for Languages: Learning, Teaching, Assessment (CEFR). Strasbourg: Cambridge University Press.

Delabastita, D. (1989). Translation and mass-communication: Film and T.V. translation as evidence of cultural dynamics. Babel (35), 194-218. 
Díaz Cintas, J. (2003). Audiovisual Translation in the Third Millennium. In G. Anderman, \& M. Rogers, Translation Today: Trends and Perspectives (pp. 192-204). Clevedon: Multilingual Matters.

Dudley-Evans, T., \& St John, M. (1998). Developements in English for Specific Purposes. A multidisciplinary approach. Cambridge: CUP.

Fuertes Olivera, P., \& Samaniego Fernández, E. (2005). El inglés para fines específicos: rasgos distintivos. In P. A. Fuertes Olivera, Lengua y sociedad: investigaciones recientes en lingüística aplicada (pp. 247-271). Valladoliz: Universidad de Valladoliz.

Joachim, M. (Director). (2010). Don't build your home, grow it! [TEDtalks] Retrieved from https://www.ted.com/talks/mitchell_joachim_don_t_build_your_home_grow_it on January $15^{\text {th }}, 2017$.

Jordan, R. (1997). English for Academic Purposes: A Guide and Resource Book for Teachers. Cambridge: Cambridge University Press.

Krashen, S., \& Terrell, T. (1983). The Natural Approach: Language Acquisition in the Classroom. Hayward, California: Alemany Press.

Letorla, J. (2012). The effect of Subtitling task on vocabulary learning. (A. Pym, \& D. Orrego-Carmona, Eds.) Translation Research Projects (4), 61-70.

Littlewood, W. (1981). Communicative Language Teaching. An Introduction. New York: Cambridge University Press.

Nunan, D. (1989). Designing Tasks for the Communicative Classroom. Cambridge: Cambridge University Press.

Prabhu, N. (1987). Second Language Pedagogy. Oxford: Oxford University Press.

Sokoli, S. (2006). Learning via Subtitling (LvS): A tool for the creation of foreign language learning activities based on film subtitling. MuTra - Audiovisual Translation Scenarios: Conference Proceedings (pp. 1-8). Copenhagen: EU-High-Level Scientific Conference Series .

Talaván, N. (2013). La subtitulación en el aprendizaje de lenguas extranjeras. Barcelona: Ediciones OCTAEDRO, S.L.

Willis, J. (1996). A flexible framework for task-based learning. Challenge and change in language teaching , 52-62.

Willis, J. (2016). A flexible framework for task-based learning. Challenge and change in language teaching, 52-62. 